\title{
Effectiveness of Teaching through Mind Mapping Technique
}

\author{
Nikhilkumar D. Parikh ${ }^{1}$
}

\section{ABSTRACT}

This Present research through mind mapping techniques has been done to check the effectiveness of teaching. For this the researcher has used Tony buzan's mind mapping technique to check the effectiveness of teaching through mind mapping. This is why the main purpose of the research the effectiveness of mind mapping technique was checked in relation to the student's academic accomplishments and for which class-8th Social Science Subject's case study for mind mapping was designed. Under this study the teaching method was taken as Independent variable where as academic accomplishment is taken as dependable variable and Gender was taken as Converter Variable. This research was experimental in nature as to check the effectiveness of the Mind Mapping technique two groups has been created. The experimental group was taught through mind mapping technique and the control group was taught through traditional method. As a sample the researcher had selected the sample of 120 students of Prerna School, a Guajarati medium High-elementary school situated in Sector-6 of Gandhinagar, Gujarat. To check the effectiveness of the mind mapping technique case criteria was formulated. Conclusions were made after getting the T-ratio based upon the average score of the test case, standard deviation and standard error of the average score and the aspect of mind mapping technique were known by the questionnaires filled and it was found that the Mind Mapping technique was more effective than Traditional method.

Keywords: Teaching, Mind Mapping Technique.

Today is the era of modern age. The whole world is on the way of progress. The basis of the country's development and advancement depends on educational system and techniques. To go step by step with the changing times education system will also need to be improved. It is not necessary that the education will be given in the same way it was given earlier. Making improvement in the education system and using new techniques is the need of the hour. New techniques can be implemented into the teaching system which suggests the need of the hour.

\footnotetext{
${ }^{1}$ Ph.D. Student, Pacific Academy of Higher Education and Research University, Udaipur, Rajasthan.

*Responding Author

(C) 2016 I N Parikh; licensee IJIP. This is an Open Access Research distributed under the terms of the Creative Commons Attribution License (http://creativecommons.org/licenses/by/2.0), which permits unrestricted use, distribution, and reproduction in any Medium, provided the original work is properly cited.
} 
Social Sciences study, in terms of maintaining motivation and development of the students it maintains the technical value for the subject and skill development. The study of the Social Science helps in developing better social values and also helps in understanding the method and techniques.

Social science's teaching in an informative manner and with clear concept makes students understand it in an easy way which can help them in further classes. Today, students are showing less interest in the social science subject of the arts stream. In today's world there is lot of awareness and it will keep on increasing day by day this is why it has become necessary to walk along with all. To solve the kind of educational problems it becomes necessary to change and improve the process of educational methods, usage and practices. To make study Simple, useful and meaningful there are many methods and functions are available. From which self realization method, CAI Method, CAL Method, conceptual map method was used as an experiment and it is very effective. A similar usage is MIND MAPPING.

According to Tony Buzan (2000), Mind mapping is an application that gives us the meaningful information to understand in a simple way. Mind Mapping Technique prepares the mind in a way that information can be used in logical and imaginary way to make an image in the brain. In Mind Mapping Technique first main idea is specified and then the linear view is explained. It is also useful for self and group in which it can have more effect than written review. This method is suitable for teachers and students for the recurrence and easy to understand hard topics. In addition, it also promotes student knowledge. This technique increases the creative power in new concepts and help to increase your motivation to study the students.

Does the implementation of the technique presented by Tony Buzan implemented in the social science subject of Primary and secondary class by using mind map method can bring changes to the education working system or not? And this study has been practiced by aiming to achieve the effectiveness. Mind mapping can be used for introducing the students with the principles and experiments of mind mapping, addition teacher teaching and making study more simple and joyful. To prepare Notes, annual plan, session plan, daily plan, text and presentation, exams and for special education programs it is being used and seen as a best method in the world.

\section{The purpose of the research}

Any job has a definite purpose. When the purpose of the job is clear it becomes the path for the research. The clear objective of the current research is below:

$>$ Teaching based on class- $8^{\text {th }}$ Topics in social science "resources" chapter by mind mapping for creating the program usage.

$>$ To check the effectiveness of the mind mapping application on the basis of experimental group and control group students of class- $8^{\text {th }}$ of social science subject's "resources" chapter. 


\section{Effectiveness of Teaching through Mind Mapping Technique}

To check the effect of gender in accomplishing the educational attainment in experimental group and control group students of class- $8^{\text {th }}$ of social science subject's "resources" chapter.

To know the suggestions based upon the effectiveness of Mind mapping technique on experimental group of students.

\section{Research Hypothesis}

The research is presented in the following void created hypothesis

$\mathbf{H O}_{1}$ There will be no significant difference between the averages of case test result of experimental group and control group students.

$\mathbf{H o}_{2}$ There will be no significant difference between the averages of case test result of experimental group's boys and girls.

$\mathbf{H 0}_{3}$ There will be no significant difference between the averages of case test result of Control group's boys and girls.

$\mathbf{H O}_{4}$ There will be no significant difference between the averages of case test result of experimental group and control group boys.

$\mathbf{H O}_{5}$ There will be no significant difference between the averages of case test result of experimental group and control group girls.

H0$_{6}$ There will be no significant difference between the averages of case test result of experimental group boys and control group girls.

$\mathbf{H 0}_{7}$ There will be no significant 1 difference between the averages of case test result of experimental group girls and control group boys.

$\mathbf{H O}_{\mathbf{8}}$ Based upon the mind mapping teaching program there will be no significant difference between the views of experimental group boys and girls.

\section{Variables in Research}

Variable means a value or component which is mobile or is personally split in nature. The property of variable is to which value can be given. Some variables included in this research are:

\section{Variables included in the study}

\begin{tabular}{|l|l|l|l|l|}
\hline S.No. & \multicolumn{1}{|c|}{$\begin{array}{c}\text { Types of } \\
\text { Variables }\end{array}$} & \multicolumn{1}{|c|}{ Variable } & \multicolumn{1}{|c|}{$\begin{array}{c}\text { Level } \\
\text { Tools }\end{array}$} \\
\hline $\mathbf{1}$ & $\begin{array}{l}\text { Independent } \\
\text { variable }\end{array}$ & Educational method & $\begin{array}{l}\text { Mind Mapping } \\
\text { Technique } \\
\text { \& Traditional } \\
\text { Method }\end{array}$ & \\
\hline $\mathbf{2}$ & $\begin{array}{l}\text { Dependent } \\
\text { variable }\end{array}$ & $\begin{array}{l}\text { Academic accomplishment, } \\
\text { significance }\end{array}$ & $\begin{array}{l}\text { Self -created unit } \\
\text { test and } \\
\text { Questionnaires }\end{array}$ \\
\hline $\mathbf{3}$ & $\begin{array}{l}\text { Moderator } \\
\text { variable }\end{array}$ & Ethnicity & Boys and Girls & \\
\hline
\end{tabular}




\begin{tabular}{|l|l|l|l|l|}
\hline $\mathbf{4}$ & $\begin{array}{l}\text { Intervening } \\
\text { variable }\end{array}$ & $\begin{array}{l}\text { Teaching Techniques, } \\
\text { Interactions between groups, } \\
\text { Student interest in the subject, } \\
\text { Individual differences in } \\
\text { students, creativeness }\end{array}$ & & \\
\hline $\mathbf{5}$ & $\begin{array}{l}\text { Control } \\
\text { variable }\end{array}$ & $\begin{array}{l}\text { Area, Medium, Class, Table of } \\
\text { Contents, School environment } \\
\text {,Number of hours }\end{array}$ & & \\
\hline
\end{tabular}

\section{Summary of previous research}

Researcher began his research and after that he tried to use previous research summary to review it. There some amendments on mind mapping usage and some amendments on conceptual map usage were found and this way the summaries of some amendments were made. Along with this the researcher has involved some paper and the article having mind mapping and conceptual map usage researching in it.

Research based on Ph.d. level by Joanne Shuttle worth (2005) ,Paul raj (2007), Raghavan Andal (1991), and Kumudha has been included. In Ph.d. level research effect of teaching applications were checked. On Mind mapping application, Joanne Shuttle worth (2005), Anthony (2006), Jasvir Kaur (2004), Thangarajathi (2006), has been incorporated. Three of these researches have been found to the effectiveness of mind mapping method. Whereas a research related to the traditional approach has been found equally effective.

Research based on M.Ed. level by Liu, P.L. \& Chen, C.J. (2008), Patel (2009) has been included. In this research it is found that in the two researches conceptual application is more effective than the traditional method. Whereas in one research it is found that the conceptual application and traditional method are equally effective. Other than this some articles and papers were also included in it and in some papers and articles mind mapping and other new techniques were also used.

In previous researches the effectiveness of mind mapping technique and conceptual map technique were tested. It was based on topics like psychology, mathematics, biology, chemistry, English and environment. Pre-research was conducted on secondary school, higher-secondary schools and a higher level. In previous researches Statistics based T-test, Co- variance analysis technique were used.

\section{Sampling}

For receiving the information a small portion (sample) is being selected to represent the whole community and the findings are applicable to the entire community, it is called sampling. (Uchaat, 2009) 
In the present research effectiveness of mind mapping technique was tested on class-8th of social science subject's "resources" chapter. For this students of academic year 2014-15 from Gandhinagar's Gujarati medium were selected. This has been defined as below.

$\begin{array}{lll}\text { Expansion } & - & \text { Gandhinagar district } \\ \text { Class } & - & 8 \\ \text { Subject } & - & \text { Social Science } \\ \text { Academic Year } & - & 2014 / 15\end{array}$

\section{Device Structure}

In the end for collecting the information researcher had made a chapter test. This test was made for Accomplishment Measurement of class- $8^{\text {th }}$ social science's topic resources. This test was of 25 marks, in which multiple choice questions fill in the blanks and short answer questions were included. And the marks obtained against the answers can be said to be the output of the research.

Opinions on mind mapping technique were taken from students of experiment base group through a questionnaire. There were total 15 provisions in this questionnaire. Against each provision agree or disagree need to be selected by $(\sqrt{ })$ mark. This can be said as the output of the research.

\section{Information gathering: methods and methodology}

Based on academic accomplishment of exams researcher had divided the students of class-8, session 2014-2015 of Prerna School into four groups (2 groups of boys and 2 groups of girls). For six days experimental group students were taught through Mind Mapping Technique and Controlled group students were taught through traditional method. After that, Chapter test and questionnaire was given to experimental group students to fill. Only Chapter test was given to the Students of controlled group to fill. And this way the information was gathered from both the groups.

\section{Chapter Test}

After six day teaching to two groups of experimental group students and 2 groups of controlled group students, the researcher had given the chapter test to be filled by the students. With the help of different invigilators Chapter Test was given at the same to all the four groups' students. To avoid any problem related to the test all the instructions were given very clearly to the students. This test was of 25 marks and 30 minutes time was given to complete the test. It was taken care that the students may not face any problem while taking the test.

\section{Questionnaire}

After the Chapter test, a questionnaire was given to fill to the Experimental group student which was scheduled from 30 minutes. _To avoid any problem related to the questionnaire all the 
instructions were given very clearly to the students. Students were asked to give clear opinions. And by using both the device researcher had collected the marks and opinion from the students.

\section{Information Analysis}

After collecting the all information, the marks obtained in the chapter test was put into the class of the variable and statistic were used for information analysis. Computer-based SPSS software was used for content analysis. Through which T-test ratio and Chi-square test can be easily attained with competence and results are authentic.

In this research T-test is used to determine the relevance of the groups. Data averages, standard deviation and T-ratio were used to check the effectiveness of teaching in social science subject through mind mapping technique. Whereas questionnaire is used to determine the meaningful differences in the opinion between the boys and girls through the use of Chi-square test $\left(\mathrm{x}^{2}\right)$.

\section{Research Conclusion}

Following are the conclusion based on the analysis and interpretation of the information gathered in this research:

- Teaching through mind mapping technique in class $-8^{\text {th }}$ resource chapter in social science's subject was more effective than the traditional method.

- There is no significant difference between the average of the scores obtained in chapter test by the Experimental group boys and girls. Therefore, there is no effect of teaching on gender through mind mapping technique.

- There is no significant difference between the average of the scores obtained in chapter test by the control group boys and girls. Therefore, there is no effect of teaching on gender through traditional technique.

- There was a significant difference between the average of the scores obtained in the chapter test by the boys of experimental and control group. Therefore, teaching through mind mapping technique is effective on experimental group of boys.

- There was a significant difference between the average of the scores obtained in the chapter test by the girls of experimental and control group. Therefore, teaching through mind mapping technique is effective on experimental group of girls.

- There was a significant difference between the average of the scores obtained in the chapter test by the experimental group of boys and controlled group of girls. Therefore, the academic success of the boys taught through mind mapping technique is more as compared to the girls taught through traditional method.

- There was a significant difference between the average of the scores obtained in the chapter test by the experimental group of girls and controlled group of boys. Therefore, the academic success of the girls taught through mind mapping technique is more as compared to the boys taught through traditional method.

- View taken from the students taught through mind mapping technique is positive. 


\section{Suggestions for future researches}

Suggestions for future research are born from complete researches. In context to this researcher had presented some valuable suggestions as follows:

- The effectiveness of the current research on mind mapping technique was tested in relation to the traditional method. Mind mapping technology can be checked in relation to the application of a conceptual map, grade study, work card system, self-study method, CAL method, CAI methodology and other techniques.

- Through mind mapping technique the effectiveness of the independent and supplementary teaching method can be judged.

- The effectiveness of mind mapping technique can be checked in the context of the student's individual variable.

- This study was conducted in a school of urban area, so this can be practiced in school of rural area too.

- In this research sample of few students were taken that can also be extended.

- In this research mind mapping technique was used in Guajarati medium school that can also be used in English or any other medium school also.

- A comparative study between rural and urban schools can be done.

- Current research is based upon the class- $8^{\text {th }}$ resources chapter of social science subject, other subjects can also be taken in the further researches.

- By using this, educational training on B.Ed, P.T.C (diploma in teaching) level can be given to check their effectiveness of teaching work and method.

- By preparing the mind map for primary school students, effectiveness can be measured.

\section{REFERENCES}

Agrawal, J.C. (1975). Educational Research. New Delhi: Arya Book Pepo.

Akinoglu, Orhan and Yasar, Zeynep (2007). "The Effects of Note Taking in Science Education Through the Mind Mapping Technique on Students'Attitudes, Achievement and Concept Learning,” Journal of Baltic Science Education, Vol. 6 (3), 34-42.

Albina. (2015), "Effectiveness of Mind Mapping Technique in Teaching of Mathematics for Standard VIII Students”. ISSN (Online): 2347-1697, International Journal of Informative \& Futuristic Research (IJIFR), Volume - 2, Issue - 12, August 2015, 24th Edition, Page No: 4630-4634. www.ijifr.com/.

Ary, D., Jacobs, L.C. and Razanch, Asghan, Introduction to Research in Education. New York: Holt Rinehart, 1972.

Best, J.W. \& Kahn, J.V. (2007). Research in Education. New Delhi: Dorling Kinder Sely.

Buch, M.B. (1992). Fifth Survey of Research in Education. New Delhi: NCERT.

Budd, John. (2007), "Mind Maps as Classroom Exercises." Regents of the University of Minnesota. Carlson School of Management. Journal of Economic Education, 35 (1), 3546. 
Buzan, (2010), Free Mind Mapping Guide, Illumine Limited, Vale House, 100 Vale Road, Windsor, Berkshire.

Buzan, T., \& Buzan, B. (2006). The Mind Map Book. BBC Books, London.

Buzan, Tony (2000), the Mind Map Book, Penguin Books. The Buzan Organisation, Ltd.

Cockburn, Elaine. (July 2011) "Can Children Create Mind Maps As Planning Tools For Writing?” Thesis submitted to the University of Nottingham, http://eprints.nottingham.ac.uk/27800/1/

Cythia, G. (2006). Encyclopedia of Education. New Delhi: Anmol Publication.

D' Antoni, Anthony V., (2009), "Relationship between the Mind Map Learning Strategy and Critical Thinking in Medical Students". Seton Hall University Dissertations and Theses (ETDs), Paper-1372, Retrieved from : http://scholarship.shu.edu/dissertations.

D. Koznov, E. Larchik, M. Pliskin, N. Artamonov, (November-2011). “Mind Maps merging in collaborative work" Programming and Computer Software,Volume-37,Issue-6,pp315321. http://link.springer.com/article.

Daniel Long., Dr. David Carlson, (2011), “Mind the Map: How Thinking Maps Affect Student Achievement”. St. Francis Xavier Elementary, Arizona State University, On-Line Journal for Teacher Research, Networks: Vol-13, Issue-2.

Farrand, P., Hussain, F. and Hennessy E. (2002), “The efficacy of the 'mind map' study technique,” Medical Education, Vol. 36 (5), pp 426-431.

Genevieve Zipp1 and Catherine Maher2. (2013). "Prevalence of mind mapping as a teaching and learning strategy in physical therapy curricula”. Journal of the Scholarship of Teaching and Learning, Vol-13, No-5, December-2013,pp.21-32. http://www.Catherine.Maher@shu.edu

Good, C.V, Barr,A.S. \& scates,D.E. (2004). Encyclopedia of Education Research Methodology: Gurgaon: Subhi Publication.

Jasvir Kaur. (2009), University Putra, Malaysia, Master of Science. "The effect of mind mapping strategies” http://www.psasir.upm.edu.my/316/

Jones, Brett D.; Ruff, Chloe; Snyder, Jennifer Dee; Petrich, Britta; and Koonce, Chelsea (2012). “The Effects of Mind Mapping Activities on Students' motivation,” International Journal for the Scholarship of Teaching and Learning:Vol.6:No.1,Article5. http://digitalcommons.georgiasouthern.edu/ijsotl/vol6/iss1/5

Kothari, C.R. (2004). Research Methodology: Methods \& Techniques. New Age International (P) Limited, Publishers. New Delhi.

Margulies, S. (1991), Mapping Inner Space: Learning and Teaching Mind Mapping. Zephyr, Tucson, AZ.

Nosratinia, M., Amini, M., \& Sarabchian, E. (2013) “The Comparative Impact of Concept Mapping and Lexical Inferencing on EFL Learners' Retention of Phrasal Verbs”. Islamic Azad University at Central Tehran, Faculty of Foreign Languages, English Department, Tehran, Iran International Journal of Language Learning and Applied Linguistics World. Volume-4(3), November-2013; 343-363, EISSN: 2289-2737 \& ISSN: 2289-3245. www.ijllalw.org 
Ozturk Demirbas, Cagri. (2013), "Perceptions of Pre-Service Social Sciences Teachers Regarding the Concept of "Geography" by Mind Mapping Technique" Educational Research and Reviews, ISSN: 1990-3839, v8 n9 p496-505, May 2013. http://academicjournals.org/ERR2.

Pei-Lin Liu, Chiu-Jung Chen, Yu-Ju Chang, (February 2010). “ Effects of a computer-assisted concept mapping learning strategy on EFL college students' English reading comprehension” Journal of Computers in Education, Volume54,Issue2, Pages436-445. http://www.sciencedirect.com/science/article.

Raghvan, A. (1999). Concept mapping in learning physical science and its relation to scholastic performance, Cognitive, ability, attitude, toward Concept mapping and science interest among standard IX student. University of madras. Chennai.

Riswanto, Pebri Prandika Putra. "The Use of Mind Mapping Strategy in the Teaching of Writing at SMAN 3 Bengkulu, Indonesia” International Journal of Humanities and Social Science, Vol. 2, No. 21, November 2012. www.ijhssnet.com/.

Seyihoglu, Aysegul; Kartal, Ayca. (2010), "The Views of the Teachers about the mind mapping technique in the Elementary Life Science and Social Studies lessons Based on the Constructivist Method," Educational Sciences: Theory and Practice, Educational Sciences: Theory and Practice,ISSN:ISSN-1303-0485,v10 n3 p1637-1656, http://files.eric.ed.gov/fulltext/EJ919863.pdf

Shuttleworth, Joanne. (2005), "Study skill use, motivation and the efficacy of the 'mind-map' technique”. University of Liverpool (University of Chester). http://hdl.handle.net/10034/76677.

Sidhu, K.S.: Methodology of Research in Education. New Delhi: Sterling Publishers Pvt. Ltd., 1985.

Suyanto, A. (2010). "The Effectiveness of Mind mapping to Teach Writing Skill Viewed from Their IQ" (An Experimental Study on the Seventh Grade Students of SMPN 1 Prambon in the Academic Year 2009/2010). Thesis. Surakarta, English Education Department of Graduate School, Sebelas Maret, University of Surakarta.

Thangarajathi, S. (2008), Effectiveness of mind mapping technique intraching mathematic. Edutracks, November, 2008, 8-3.

White, R. and Gunstone, R. (1992), Probing Understanding. Falmer Press, New York.

Xiao-qiang Liu, (February 2015) "Online mind-map as interface of electronic resource integration and sharing” Journal of Shanghai Jiaotong University (Science), Volume-20, Issue-1, pp-101-105. http://link.springer.com/article. 